JOURNAL OF ENGINEERING SCIENCES

ЖУРНАЛ ІНЖЕНЕРНИХ НАУК

ЖУРНАЛ ИНЖЕНЕРНЫХ НАУК

Web site: http://jes.sumdu.edu.ua

DOI: $10.21272 /$ jes.2019.6(2).b1

Volume 6, Issue 2 (2019)

\title{
Dynamic Modulus and Field Performance of Cold-in-Place Recycled Asphalt Pavement
}

\author{
Islam M. R. ${ }^{1 *}$, Kalevela S. A. ${ }^{1}$, Rivera J. A. ${ }^{1}$, Rashid T. B. ${ }^{2}$ \\ ${ }^{1}$ Department of Engineering Technology, Colorado State University, Pueblo, CO 81001, Colorado, USA; \\ ${ }^{2}$ Department of Electrical and Computer Engineering, University of Colorado at Colorado Springs, CO 81001, Colorado, USA
}

Article info:

Paper received:

The final version of the paper received:

Paper accepted online:
September 1, 2019

November 23, 2019

November 28, 2019
*Corresponding Author's Address:

md.islam@csupueblo.edu

\begin{abstract}
This study investigates the dynamic modulus of cold-in-place recycling (CIR) asphalt material and its performance using pavement performance data and laboratory dynamic modulus testing. Colorado Department of Transportation (CDOT) has 37 projects with over 8 million square yards using CIR materials. Sites from ten projects were selected to monitor the performances and collect samples for laboratory testing. Dynamic modulus testing on the CIR cores was conducted by the CDOT. Results show measured distresses of CIR rehabilitation techniques are mostly below the threshold values during the service period. International Roughness Index, rutting, and transverse cracking never exceeded the threshold values during the studied period. Only two CIR pavements exceeded the threshold values for fatigue cracking after 8-10 years of service. Measured distresses of CIR rehabilitation techniques are similar to conventional pavements based on engineering judgment. The laboratory dynamic modulus test results show CIR has about $50 \%$ less dynamic modulus compared to the traditional asphalt mixture.
\end{abstract}

Keywords: asphalt pavement, cold-in-place recycling, dynamic modulus, fatigue cracking, transverse cracking.

\section{Introduction}

With the advancement of milling equipment and a rise in asphalt binder's price, pavement rehabilitation becomes very popular in different pavement design and construction agencies. Of the several rehabilitation technologies, Cold-in-Place Recycling (CIR) technology may be the cheapest and the environment-friendliest compared to the others. To adopt this technology, its properties and performance data must be available to the pavement design and construction agencies.

Recycling of Hot-Mix Asphalt (HMA) has increased in popularity since the late 1970 s, primarily due to increased oil prices. Previously, the cost of recycling old pavements was greater than placing the new HMA (1996). The invention of milling machines allowed asphalt recycling to become more cost-effective compared to new construction (Cross and Jakatimath, 2007). Coldin-Place Recycling (CIR) is the processing and treatment of existing HMA pavements to restore the pavement without heating the asphaltic materials (ARRA 2014).

The deteriorated top 2 to 4 inches of HMA is removed by a milling machine and the milled material is crushed and screened on-site to produce a specified gradation. Binding additives such as emulsion, cement, lime, or fly ash are mixed into the milled material. The mixture is then placed back on the roadway and graded to the final elevation. After compaction of the mixture, a fog seal or thin overlay may be applied if traffic volume is relatively high.

CIR is economically and environmentally beneficial for it uses less aggregate, does not need transportation of materials to and from the site, and involves less energy consumption. The use of CIR is environment-friendly as it may decrease carbon dioxide emission by up to $9 \%$ compared to traditional HMA mixes; the carbon dioxide emission is $54 \%$ less considering the phase of recycling only (Giani et al., 2015). In 2016, Schwartz reported that CIR technologies decrease the carbon dioxide emission by $80 \%$ compared to traditional HMA application. Additionally, CIR technology saves $60 \%$ asphalt binder compared to HMA.

\section{Literature Review}

In 2007, Cross and Jakatimath compared the properties and performances of CIR to conventional HMA mixtures used in Oklahoma by laboratory and field investigation and found that CIR material is comparable with conventional HMA mixture. In laboratory samples, they found that CIR mixtures were not as stiff as typical HMA mixtures. CIR mixtures showed the same increase in stiffness 
with long-term oven aging as did conventional HMA samples. Field evaluation consisted of rehabilitating two sections with CIR and slurry crack injection to retard reflection cracking. A third section was rehabilitated with more conventional treatment of a fabric interlayer and HMA overlay. They conducted field distress surveys for three years at which time the two CIR test sections had less transverse cracking than the conventional test section. Based on this research, CIR appears to be a viable procedure for rehabilitation of transverse cracked pavements. Schwartz [5] showed the dynamic modulus of CIR is approximately $50 \%$ of the conventional HMA. The study also determined that CIR is $18 \%$ lighter than conventional HMA and requires an additional $25 \%$ of thickness to obtain the same strength of HMA.

In 2015, Bhavsar conducted laboratory tests and field observation for long-term CIR performance using two different Reclaimed Asphalt Pavement (RAP) mixtures. The purpose of this study was to compare two types of CIR materials: 1) full CIR and 2) CIR with conventional asphalt mixtures. Using visual inspections, Bhavsar found large amounts of deteriorations where a greater number of trucks, poor drainage, and low speeds were prevalent. This study did not show a difference in laboratory or field performance between the two mixtures. Based on a field survey, Kim et al. [7] found, CIR roads would last between 21 and 25 years based on the best-fit regression model where the roads were predicted to reach a fair pavement condition. The average service life of CIR roads with good subgrade support was predicted to last up to 34 years, whereas that of CIR roads with poor subgrade support was predicted to last up to 22 years. CIR is applicable for lower volume roads that may only require simple surface treatment. A cracked pavement may be restored by CIR if it is structurally sound and has welldrained bases and subgrade. CIR is generally not appropriate for pavement with excessive rutting, unstable basesubgrade, and moisture-related damage that cannot be fully recycled by the depth of the CIR treatment applied to the roadway.

In 2009, Kim et al. recommended the material characterization tests such as penetration and dynamic shear rheometer tests be performed for the residual asphalt in RAP materials. In 2007, Kim et al. conducted dynamic modulus and repeated load tests on CIR foam mixtures with RAP materials collected from different CIR project sites. It was found that both the dynamic modulus and flow number were dependent on the RAP sources and foamed asphalt constituents. In 2009, Kim and Lee prepared foamed CIR samples at different temperatures and conducted indirect tensile strength tests to determine whether the RAP temperature would affect the strength of the CIR materials. After testing the samples, they found that temperature of RAP materials has a significant impact on the wet indirect tensile strength of CIR foam mixtures and the optimum foam content differs with the temperature. In 2019, Islam et al. found an equivalent hot-mix asphalt for a cold mix. However, the field performance is cold mix is yet to be known.
From the above discussion, the mechanical properties and performance of CIR are dependent on RAP sources and properties, and the residual binders. The local study is essential to determine the performance and measurement of CIR's effectiveness. The main objective of this research is to evaluate the effectiveness of the CIR in Colorado's pavement. Specific objectives are mentioned below:

- to evaluate the performance of the CIR rehabilitated pavements with comparison to the conventional pavements;

- to document and recommend the dynamic modulus values of CIR materials for mechanistic pavement design.

\section{Research Methodology}

\subsection{Materials collection}

Ten asphalt cores were collected from each site. Samples collected had the following characteristics:

- CIR cores were bound materials;

- layer separation between the CIR and underlying HMA bonding was common;

- the bottom layer (old asphalt layer) had deteriorated. Since the CIR layer was a bound material, it was possible to conduct dynamic modulus tests.

The CIR material used in this study uses emulsion as the softening agent. In 2017, it was obtained that emulsion is also used in producing the warm-mix-asphalt.

\subsection{Dynamic modulus testing}

In 2010, the dynamic modulus testing on collected field cores following the AASHTO TP 62 test protocol using the Asphalt Mixture Performance Tester (AMPT) testing device. The procedure is described below:

- label each core and identify the cold-in-place layer using construction data and by visually inspecting each core. The diameter of the cores collected from the sites is $150 \mathrm{~mm}$;

- cut a $50 \mathrm{~mm}$ diameter core horizontally out of the cold-in-place layer;

- trim the cores to $110 \mathrm{~mm}$ in height;

- record the exact measurements of each $110 \mathrm{~mm}$ specimen;

- attach the gauge points for an AMPT instrumentation;

- run the dynamic modulus test on each specimen at 4 , 20 , and $35^{\circ} \mathrm{C}$ at $0.1,1.0$, and $10.0 \mathrm{~Hz}$ respectively.

\subsection{Dynamic modulus test results}

Six dynamic modulus tests have been conducted for each test site and the average results are used in the analysis. Mastersolver was used to determine the master curve of dynamic modulus to be used in the PMED software. The dynamic modulus is determined using the following equation:

$\log \left|E^{*}\right|=\log (\operatorname{Min})+\frac{(\log (\text { Max })-\log (\operatorname{Min}))}{1+e^{\beta+\gamma \log \omega_{\gamma}}}$ 
where $\left|E^{*}\right|$ - dynamic modulus; $\omega_{r}$ - the reduced frequency, Hz; Max - limiting maximum modulus, ksi; Min - limiting minimum modulus, ksi; $\beta, \gamma$ - fitting parameters. The reduced frequency is computed using the Arrhenius given below:

$$
\log \left(\omega_{r}\right)=\log \omega+\frac{\Delta E_{a}}{19.14714}\left(\frac{1}{T}-\frac{1}{T_{r}}\right)
$$

where $\omega_{r}-$ the reduced frequency at the reference temperature; $\omega$ - loading frequency at the test temperature; $T_{r}$ - reference temperature, $\mathrm{K} ; T$ - test temperature, $\mathrm{K} ; \Delta E_{a}-$ activation energy (treated as a fitting parameter).

The combination of the above mentioned two equations gives the following equation:

$$
\log \left|E^{*}\right|=\log (\operatorname{Min})+\frac{(\log (\operatorname{Max})-\log (\operatorname{Min}))}{1+e^{\beta+\gamma}\left\{\log \omega+\frac{\Delta E_{a}}{19.14714}\left(\frac{1}{T}-\frac{1}{T_{r}}\right)\right\}}
$$

The shift factors for each temperature are given by the following equation:

$$
\log [a(T)]=\frac{\Delta E_{a}}{19.14714}\left(\frac{1}{T}-\frac{1}{T_{r}}\right)
$$

where $a(T)$ - shift factor at temperature $T$.

The maximum limiting modulus is estimated from mixture volumetric properties using the Hrisch model shown below and a limiting binder modulus of $1 \mathrm{GPa}$ :

$$
\begin{aligned}
& \left|E^{*}\right|_{\max }=P_{c}\left[4,200,000\left(1-\frac{V M A}{100}\right)+435,000\left(\frac{V M A x V F A}{10,000}\right)\right] \\
& +\frac{1-P_{c}}{\left[\frac{\left(1-\frac{V M A}{100}\right)}{4,200,000}+\frac{V F A}{435,000 V F A}\right]} \\
& \quad \text { where }
\end{aligned}
$$

$$
P_{c}=\frac{\left(20+\frac{435,000 V F A}{V M A}\right)^{0.58}}{650+\left(\frac{435,000 V F A}{V M A}\right)^{0.58}}
$$

$\left|E^{*}\right|_{\max }$ - limiting maximum dynamic modulus, psi; VMA - voids in mineral aggregates, \%; VFA - voids filled with asphalt, \%.

\section{Results}

\subsection{Average raw dynamic modulus}

To determine a recommended dynamic modulus for CIR from AMPT (master curve) data, the average raw dynamic modulus, VMA and VFA of all ten sites were combined, the average value calculated, and then fitted using the Mastersolver.
The average raw dynamic modulus data are presented in Table 1.

Table 1 - Average raw dynamic modulus of ten sites

\begin{tabular}{|c|c|c|}
\hline $\begin{array}{c}\text { Temperature, } \\
{ }^{\circ} \mathrm{C}\end{array}$ & $\begin{array}{c}\text { Frequency, } \\
\mathrm{Hz}\end{array}$ & $\begin{array}{c}\text { Modulus, } \\
\mathrm{ksi}\end{array}$ \\
\hline 4 & 0.1 & 753 \\
\hline 4 & 1.0 & 918 \\
\hline 4 & 10.0 & 1100 \\
\hline 20 & 0.1 & 419 \\
\hline 20 & 1.0 & 512 \\
\hline 20 & 10.0 & 678 \\
\hline 35 & 0.01 & 135 \\
\hline 35 & 0.1 & 181 \\
\hline 35 & 1.0 & 266 \\
\hline 35 & 10.0 & 401 \\
\hline
\end{tabular}

The average VMA and VFA are $13.3 \%$ and $26.6 \%$ respectively. After the execution of the Mastersolver, the final parameters and the fitting parameters are given below. The PMED input modulus is listed in Table 2: $\left|E^{*}\right|_{\max }=3102.4 \mathrm{ksi} ;\left|E^{*}\right|_{\min }=0.5 \mathrm{ksi} ; \beta=1.34 ; \gamma=0.19$; $\Delta E_{a}=241692 \mathrm{~Pa} ; R_{2}=0.989 ; S_{e} / S_{y}=0.07$.

The dynamic modulus for all 10 sites has been plotted in Figure 1. The figure also has one conventional (NMAS $=12.5 \mathrm{~mm}, \mathrm{PG}$ 64-22 binder and 100 gyrations) mixtures' dynamic modulus for the comparison. The volume characteristics of the conventional mixtures are the same as the CIR mixtures as both have the same mix design. There are several reasons for comparing the dynamic modulus of CIR and that of a conventional mix. Dynamic modulus is the primary material property used in the mechanistic-empirical pavement design. Lower dynamic modulus at lower frequency of loading (or high temperature) dictates that the mix is very susceptible to rutting as less stiff material at high temperature deform a lot. On the other hand, lower dynamic modulus at higher frequency of loading (or low temperature) dictates that the mix is good against low-temperature cracking. Figure 5 shows that at lower reduced frequency (or higher temperature zone), the dynamic modulus of CIR materials are higher than that of the control mixture. At higher reduced frequency (or lower temperature), the dynamic modulus of CIR materials is smaller (roughly $50 \%$ ) than that of the control mixture. This means CIR is more susceptible to rutting but less susceptible to cracking compared to conventional mixtures. The fitted dynamic modulus (named as "Fit" in Figure 1), lies almost in the middle of the all dynamic modulus range. The fitted dynamic modulus data can be used by CDOT for future CIR overlay design. As full details of CIR of individual sites are not available, different dynamic modulus values for different CIR mixes cannot be recommended.

\subsection{Field performance data collection}

Ten pavement sites where CIR has been used were selected for this research. A control site was selected for each test site for comparison of the CIR pavement versus traditional HMA pavement. The control sites were selected and were chosen for being the best fit for pavement 
location, materials, geometry, climate, traffic volume, and time of construction (i.e., the projects were built during the same year or close to the year. The control test sites were located near the CIR sites. It is important to mention that the control sites were not constructed using CIR technology, rather traditional HMA.

Table 2 - Fitted dynamic modulus of CIR material

\begin{tabular}{|c|c|c|c|c|c|c|c|}
\hline \multirow{2}{*}{ No. } & \multicolumn{2}{|c|}{ Temperature } & \multirow{2}{*}{$\begin{array}{c}\text { Frequency } \\
\mathrm{Hz}\end{array}$} & \multirow{2}{*}{$\begin{array}{l}\text { Shift } \\
\text { factor }\end{array}$} & \multirow{2}{*}{$\begin{array}{l}\text { Reduced } \\
\text { frequency }\end{array}$} & \multicolumn{2}{|c|}{$E^{*}$} \\
\hline & ${ }^{\circ} \mathrm{C}$ & ${ }^{\circ} \mathrm{F}$ & & & & ksi & GPa \\
\hline 1 & -10.0 & 14 & 25 & 4.91 & 2018759 & 1664.7 & 11.48 \\
\hline 2 & -10.0 & 14 & 10 & 4.91 & 807503 & 1590.4 & 10.97 \\
\hline 3 & -10.0 & 14 & 5 & 4.91 & 403751 & 1533.3 & 10.58 \\
\hline 4 & -10.0 & 14 & 1 & 4.91 & 80750 & 1398.5 & 9.65 \\
\hline 5 & -10.0 & 14 & 0.5 & 4.91 & 40375 & 1339.8 & 9.24 \\
\hline 6 & -10.0 & 14 & 0.1 & 4.91 & 8075 & 1203.2 & 8.30 \\
\hline 7 & 4.4 & 40 & 25 & 2.41 & 6456 & 1184.3 & 8.17 \\
\hline 8 & 4.4 & 40 & 10 & 2.41 & 2582 & 1107.0 & 7.64 \\
\hline 9 & 4.4 & 40 & 5 & 2.41 & 1291 & 1049.2 & 7.24 \\
\hline 10 & 4.4 & 40 & 1 & 2.41 & 258 & 917.6 & 6.33 \\
\hline 11 & 4.4 & 40 & 0.5 & 2.41 & 129 & 862.6 & 5.95 \\
\hline 12 & 4.4 & 40 & 0.1 & 2.41 & 25 & 739.8 & 5.10 \\
\hline 13 & 21.1 & 70 & 25 & -0.16 & 17.19515 & 710.1 & 4.90 \\
\hline 14 & 21.1 & 70 & 10 & -0.16 & 6.87806 & 645.1 & 4.45 \\
\hline 15 & 21.1 & 70 & 5 & -0.16 & 3.43903 & 598.0 & 4.12 \\
\hline 16 & 21.1 & 70 & 1 & -0.16 & 0.68781 & 496.3 & 3.42 \\
\hline 17 & 21.1 & 70 & 0.5 & -0.16 & 0.34390 & 455.8 & 3.14 \\
\hline 18 & 21.1 & 70 & 0.1 & -0.16 & 0.06878 & 370.2 & 2.55 \\
\hline 19 & 37.8 & 100 & 25 & -2.46 & 0.08645 & 381.7 & 2.63 \\
\hline 20 & 37.8 & 100 & 10 & -2.46 & 0.03458 & 337.2 & 2.33 \\
\hline 21 & 37.8 & 100 & 5 & -2.46 & 0.01729 & 306.1 & 2.11 \\
\hline 22 & 37.8 & 100 & 1 & -2.46 & 0.00346 & 242.1 & 1.67 \\
\hline 23 & 37.8 & 100 & 0.5 & -2.46 & 0.00173 & 217.9 & 1.50 \\
\hline 24 & 37.8 & 100 & 0.1 & -2.46 & 0.00035 & 169.1 & 1.17 \\
\hline 25 & 54.4 & 130 & 25 & -4.53 & 0.00074 & 191.1 & 1.32 \\
\hline 26 & 54.4 & 130 & 10 & -4.53 & 0.00030 & 165.1 & 1.14 \\
\hline 27 & 54.4 & 130 & 5 & -4.53 & 0.00015 & 147.4 & 1.02 \\
\hline 28 & 54.4 & 130 & 1 & -4.53 & 0.00003 & 112.5 & 0.78 \\
\hline 29 & 54.4 & 130 & 0.5 & -4.53 & 0.00001 & 99.9 & 689.0 \\
\hline 30 & 54.4 & 130 & 0.1 & -4.53 & 0.00000 & 75.4 & 519.9 \\
\hline
\end{tabular}

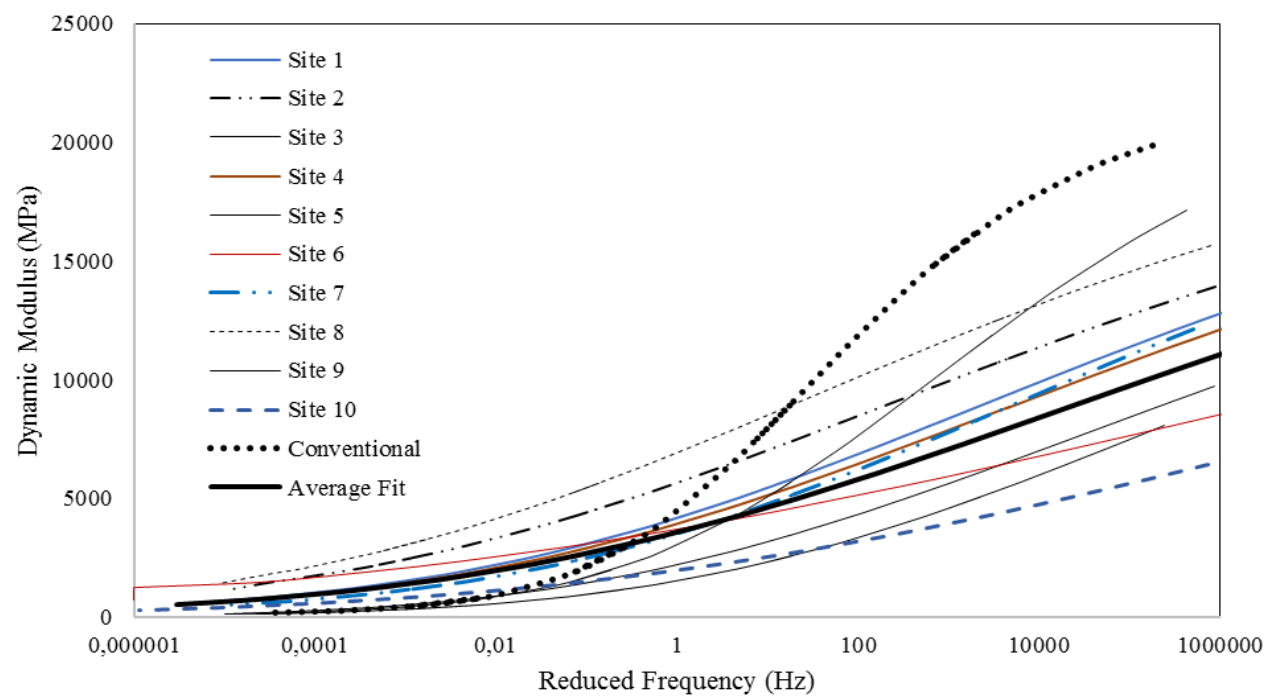

Figure 1 - Dynamic modul of all mixes including conventional mixtures

To collect the pavement management data, an automated data collection van is driven over the entire roadway network. The collected data are reported in tenth-ofmile (tenth-mile) increments and include surface rough- ness (IRI), permanent deformation (rutting), and fatigue cracking. The definitions of the distress measured are provided below. The International Roughness Index (IRI) is the roughness index most commonly obtained from 
measured mean longitudinal road profiles of each wheel path. IRI is a quantification of functional adequacy and is calculated using a quarter-car vehicle math model, whose response is accumulated to yield a roughness index with units of slope, $\mathrm{mm} / \mathrm{km}$. IRI is the cumulative effect of rutting, fatigue cracking, and thermal cracking.

Rutting is the longitudinal surface depression in the wheel path resulting from the permanent deformation in each pavement layer along the wheel path. Ruts are particularly evident after a rain when they are filled with water. The rut depth is the vertical difference in elevation between the transverse profile of the surface and a wireline across the lane width.

Fatigue cracks consist of both the bottom-up and the top-down fatigue cracking. A series of interconnected cracks looking similar to a chicken wire or back of an alligator is defined as the bottom-up cracking. This crack initiates at the bottom of asphalt layer for the repeated tensile strain due to repeated (fatigue) wheel load-related and propagates to the surface. Therefore, this crack is often called the bottom-up fatigue crack. Longitudinal cracks, near the wheel paths, parallel to the centerline of the roadway are called the top-down longitudinal cracks. The top-down longitudinal cracks initiate at the surface of asphalt layer due to repeated tensile and/or shear strain caused by wheel loading. They can also develop along the construction joint between adjacent passes of the paver or at a location that corresponds to the center of the paver.

Transverse top-down surface cracking (also known as transverse cracking or thermal cracking) is caused by single cooling due to extreme cold temperature or high rate of cooling may cause low-temperature cracking. Low-temperature cracking occurs when the induced tensile stress by the decrease in temperature exceeds the tensile strength of the asphalt concrete.

The collection of the rutting data is accomplished using a five-sensor rut bar that measures the pavement's permanent deformation to the hundredth of an inch. The IRI data is collected with an inertia profile consisting of laser sensors, accelerometer, and distance transducer. The van is also equipped with digital cameras; one camera is positioned for a windshield view, and four cameras (one over each wheel) to view the pavement. The cameras take photos/videos of the pavement showing the type, amount, length, and severity of the cracking. The data collected is recorded and sent to the vendor's data reduction office where it is viewed and rated. The raw data is given in tenth-mile intervals. Thus, IRI is reported as the average $\mathrm{mm} / \mathrm{km}$ over a tenth-mile section. Bottom-up fatigue cracking is reported as percentage of total lane cracked and is defined by a series of small, jagged, interconnecting cracks caused by failure of the asphalt concrete surface under repeated traffic loading. Top-down longitudi- nal cracking is reported as the total linear feet in a tenthmile and is defined as cracking that is parallel to the pavement centerline. The top-down longitudinal cracking with bottom-up fatigue cracking was combined and refer as fatigue cracking. Transverse cracks are reported in two different ways, first as a numerical count such as 1,2 , or 3 per tenth-mile, the second is by linear feet per tenthmile. Transverse cracks are defined as cracking that is perpendicular to the pavement centerline.

\subsection{Pavement performance summary}

Field performance data for fatigue cracking, rutting, transverse cracking, and IRI were collected from 10 selected sites using CIR and 10 control sites constructed using conventional HMA. Two types of comparisons were made, first, with the CDOT recommended threshold values of performance criteria for the rehabilitation of flexible pavement projects obtained from the CDOT 2017 Pavement Design Manual [15], and second, with the distresses of the control sites. Table 3 summarizes the maximum distress data collected from 10 selected sites using CIR and 10 control sites using conventional HMA.

Table 4 lists the recommended threshold values of performance criteria for rehabilitation of flexible pavement projects. First, IRI, Rutting and Transverse Cracking did not exceed the threshold values during the service period. For fatigue cracking, CIR exceeds the threshold value at Site 5, and Site 8 after $8-10$ years of service. All these locations are from Interstates (I-25 and I-70). Most distress data for interstates are within the threshold values. Due to high volume of traffic, CIR may not be an appropriate option for interstates.

The comparison of the measured distresses with the control sites is summarized in Table 5. It shows CIR performed better at three sites, similar at one site and worse at six sites compared to the control projects for fatigue cracking. Results of rutting show CIR performed better at four sites, similar at two sites and worse at four sites compared to the control site. For transverse cracking, CIR performed better at five sites, and worse at five sites compared to the control projects. CIR performed better at four sites, and worse at six sites compared to the control projects for IRI. Considering all these results, it can be said that measured distresses of CIR rehabilitation techniques are similar to conventional pavements.

Combining all the data, it shows that CIR performs better for $40 \%$ distresses, similar for $7.5 \%$ distresses, and worse for $52.5 \%$ distresses compared to the traditional pavement. Thus, it can be said that CIR is very similar to conventional pavements based on engineering judgment. However, CIR technology has about $50 \%$ cost saving as discussed in the literature and it has many more benefits considering environment for energy-saving and less pollution, traffic control, noise, dust, and so on. 
Table 3 - Measured maximum distresses

\begin{tabular}{|c|c|c|c|c|c|c|c|}
\hline Project & $\begin{array}{c}\text { Average } \\
\text { annual daily } \\
\text { traffic } \\
\text { AADT }\end{array}$ & $\begin{array}{l}\text { Years } \\
\text { of data }\end{array}$ & Location & $\begin{array}{c}\text { IRI } \\
\mathrm{mm} / \mathrm{km}\end{array}$ & $\begin{array}{c}\text { Rutting } \\
\mathrm{mm}\end{array}$ & $\begin{array}{l}\text { fatigue } \\
\text { cracking } \\
\% \text { of lane }\end{array}$ & $\begin{array}{l}\text { No. of } \\
\text { transverse } \\
\text { cracking }\end{array}$ \\
\hline \multirow{2}{*}{ Site 1} & \multirow{2}{*}{4000} & \multirow{2}{*}{9} & CIR & 1121 & 4.6 & 0.95 & 11 \\
\hline & & & Control Site & 1405 & 4.8 & 2.42 & 8 \\
\hline \multirow{2}{*}{ Site 2} & \multirow{2}{*}{4800} & \multirow{2}{*}{9} & CIR & 1957 & 8.4 & 0.22 & 8 \\
\hline & & & Control Site & 1783 & 6.1 & 1.23 & 24 \\
\hline \multirow{2}{*}{ Site 3} & \multirow{2}{*}{11000} & \multirow{2}{*}{9} & CIR & 1594 & 4.1 & 0.70 & 3 \\
\hline & & & Control Site & 994 & 4.3 & 0.65 & 7 \\
\hline \multirow{2}{*}{ Site 4} & \multirow{2}{*}{2200} & \multirow{2}{*}{5} & CIR & 1342 & 4.6 & 0.20 & 1 \\
\hline & & & Control Site & 1215 & 3.6 & 1.12 & 5 \\
\hline \multirow{2}{*}{ Site 5} & \multirow{2}{*}{19000} & \multirow{2}{*}{8} & CIR & 1263 & 5.8 & $48.12 *$ & 55 \\
\hline & & & Control Site & 852 & 5.6 & 4.00 & 18 \\
\hline \multirow{2}{*}{ Site 6} & \multirow{2}{*}{3000} & \multirow{2}{*}{10} & CIR & 1499 & 6.1 & 7.18 & 7 \\
\hline & & & Control Site & 1278 & 5.6 & 0.42 & 2 \\
\hline \multirow{2}{*}{ Site 7} & \multirow{2}{*}{7400} & \multirow{2}{*}{10} & CIR & 1215 & 6.1 & 13.52 & 18 \\
\hline & & & Control Site & 1105 & 8.9 & 8.98 & 6 \\
\hline \multirow{2}{*}{ Site 8} & \multirow{2}{*}{20000} & \multirow{2}{*}{10} & CIR & 1294 & 4.3 & $26.15^{*}$ & 135 \\
\hline & & & Control Site & 1326 & 6.4 & 13.23 & 11 \\
\hline \multirow{2}{*}{ Site 9} & \multirow{2}{*}{12000} & \multirow{2}{*}{11} & CIR & 963 & 7.4 & 13.13 & 5 \\
\hline & & & Control Site & 1357 & 4.6 & 11.35 & 24 \\
\hline \multirow{2}{*}{ Site 10} & \multirow{2}{*}{12000} & \multirow[b]{2}{*}{8} & CIR & 1231 & 6.1 & 0.30 & 1 \\
\hline & & & Control Site & 1641 & 4.1 & 4.68 & 27 \\
\hline
\end{tabular}

* recommended by CDOT.

Table 4 - Recommended threshold values of performance criteria for rehabilitation of flexible pavement projects

\begin{tabular}{|c|c|c|c|c|}
\hline Project & $\begin{array}{c}\text { IRI, } \\
\mathrm{mm} / \mathrm{km}\end{array}$ & $\begin{array}{c}\text { Rutting, } \\
\mathrm{mm}\end{array}$ & $\begin{array}{c}\text { Total } \\
\text { fatigue } \\
\text { cracking, } \\
\% \text { of lane }\end{array}$ & $\begin{array}{c}\text { No. of } \\
\text { transverse } \\
\text { cracking }\end{array}$ \\
\hline Interstate & 2525 & 14.0 & 23.3 & 125 \\
\hline $\begin{array}{c}\text { Principal } \\
\text { arterial }\end{array}$ & 3157 & 16.5 & 39.2 & 125 \\
\hline
\end{tabular}

\section{Conclusions}

Based on the study, the following conclusions are made. Firstly, measured distresses of CIR rehabilitation techniques are mostly below the threshold values during the service period. IRI, Rutting and Transverse Cracking never exceeded the threshold values during the studied period. Only two CIR pavements exceeded the threshold values for fatigue cracking after 8-10 years of service. Secondly, measured distresses of CIR rehabilitation techniques are similar to conventional pavement based on engineering judgment. Finally, the CIR has a smaller dynamic modulus compared to the conventional asphalt mixture at low temperature (or high frequency).
Table 5 - CIR performance compared to conventional pavement, sites no.

\begin{tabular}{|c|c|c|c|}
\hline Performances & $\begin{array}{c}\text { Locations } \\
\text { favoring } \\
\text { the CIR }\end{array}$ & $\begin{array}{c}\text { Neutral } \\
\text { locations }\end{array}$ & $\begin{array}{c}\text { Locations } \\
\text { against } \\
\text { the CIR }\end{array}$ \\
\hline Fatigue cracking & $1,4,10$ & 3 & $2,5-9$ \\
\hline Rutting & $1,3,7,8$ & 5,6 & $2,4,9,10$ \\
\hline Transverse cracking & $2-4,9,10$ & - & $1,5-8$ \\
\hline IRI & $1,8-10$ & - & $2-7$ \\
\hline Total no. & 16 & 3 & 21 \\
\hline
\end{tabular}

The conclusions drawn in the previous section are based on limited data available from the current study. Future research should incorporate cement-treated or foam treated material to determine the best CIR product. The effect of emulsion content may also be studied.

\section{Acknowledgments}

The Colorado State University-Pueblo (CSU-Pueblo) research team appreciates the research funding (Funding No. CDOT 415.02) by the Colorado Department of Transportation (CDOT). 


\title{
References
}

1. AASHTO TP 62 (2010). Standard Method of Test for Determining Dynamic Modulus of Hot-Mix Asphalt Concrete Mixtures, AASHTO Designation TP 62. AASHTO Provisional Standards, AASHTO, Washington DC.

2. ARRA (2014). Basic Asphalt Recycling Manual, 2nd Edition, Asphalt Recycling \& Reclaiming Association (ARRA), Annapolis, Maryland.

3. Bhavsar, J. (2015). Comparing Cold In-Place Recycling (CIR) and Cold In-Place Recycling with Expanded Asphalt Mixture (CIREAM). M.Sc. thesis, Department of Civil Engineering, University of Waterloo, Ontario, Canada.

4. CDOT (2017). CDOT M-E Pavement Design Manual. Colorado Department of Transportation, Denver, CO.

5. Cross, S. A., Jakatimath, Y. (2007). Evaluation of Cold In-Place Recycling for Rehabilitation of Transverse Cracking on US 412, Report No. FHWA/OK 07 (04), Oklahoma Department of Transportation, Planning and Research Division, Oklahoma City, OK.

6. Giani, M., Dotelli, G., Brandini, N., Zampori, L. (2015). Comparative life cycle assessment of asphalt pavements using reclaimed asphalt, warm mix technology and cold in-place recycling. Resources, Conservation and Recycling, Vol. 104, pp. 224238.

7. Islam, M. R., Kalevela, S. A., Rivera, J. A. (2019). Finding an Equivalent Hot-Mix Asphalt for Cold-in-Place Recycled Asphalt suing Laboratory Testing and Numerical Analysis. Journal of Engineering Science, King Saud University, doi: 10.1016/j.jksues.2019.10.001.

8. Kim, J., Lee, H., Jahren, C., Heitzman, M., Chen, D. (2009). Long-Term Field Performance of Cold In-Place Recycled Roads in Iowa. Journal of Performance of Constructed Facilities, Vol. 24(3) pp. 265-274.

9. Kim, Y., Lee, H., Heitzman, M. (2007). Validation of New Mix Design Procedure for Cold In-Place Recycling with Foamed Asphalt. Journal of Materials in Civil Engineering, Vol. 19(11), pp. 1000-1010.

10. Kim, Y., Lee, H., Heitzman, M. (2009). Dynamic Modulus and Repeated Load Tests of Cold In-Place Recycling Mixtures Using Foamed Asphalt. Journal of Materials in Civil Engineering, Vol. 21(6), pp. 279-285.

11. Roberts, F. L., Kandhal, P. S., Brown, E. R., Lee, D.-Y., Kennedy, T. W. (1996). Hot Mix Asphalt Materials, Mixture Design, and Construction. NAPA Research and Education Foundation.

12. Schwartz, C. W. (2016). Structural Characteristics and Environmental Benefits of Cold-Recycled Asphalt Paving Materials. National Pavement Preservation Conference, October 12-14, 2016, Nashville, TN

УДК $625.7 / .8$

\section{Динамічний модуль та експлуатаційні характеристики переробленого асфальтового покриття}

\author{
Islam M. R. ${ }^{1 *}$, Kalevela S. A. ${ }^{1}$, Rivera J. A. ${ }^{1}$, Rashid T. B. ${ }^{2}$
}

\footnotetext{
${ }^{1}$ Кафедра інженерних технологій, Державний університет Колорадо, 81001, м. Пуебло, штат Колорадо, США;

${ }^{2}$ Кафедра електротехніки та комп’ютерної інженерії, Університет Колорадо в Колорадо-Спрінгс, 81001, м. Пуебло, штат Колорадо, США
}

\begin{abstract}
Анотація. У цьому дослідженні вивчається динамічний модуль асфальтового матеріалу та продуктивність його перероблення за допомогою даних про експлуатацію та лабораторних випробувань. Кафедра транспорту Колорадо має 37 проектів з використання даного матеріалу площею більше 8 км². Для відстеження результатів і збирання дослідних матеріалів для лабораторних досліджень було відібрано зразки з десяти проектів. Тестування динамічного модуля для даного матеріалу відбувалось у лабораторії кафедри транспорту Державного університету Колорадо. Результати свідчать про те, що досліджувані показники якості $є$ переважно нижчими за порогові значення впродовж періоду експлуатації. Зокрема, міжнародний показник шорсткості та поперечне розтріскування ніколи не перевищували порогові значення впродовж усього періоду дослідження. Лише два асфальтні покриття перевищили порогові показники для втомних тріщин після 8-10 років експлуатації. Грунтуючись на технічних міркуваннях, виміряні показники аналогічні до показників для звичайних тротуарів. Результати лабораторних досліджень показали, що матеріал має приблизно на 50 \% менший динамічний модуль порівняно з традиційною асфальтовою сумішшю.
\end{abstract}

Ключові слова: асфальтне покриття, холодне перероблення на місці, динамічний модуль, втомна тріщина, поперечне розтріскування. 